\title{
Livelihoods Used by Street Children for Survival in Bamako, Mali
}

\author{
Oumou Diallo ${ }^{1}$, Guang Xin Wang ${ }^{1} \&$ Hamadoun H. Toure ${ }^{2}$ \\ ${ }^{1}$ School of Humanities and Social Sciences, Beijing Forestry University, Beijing, China \\ ${ }^{2}$ Faculté des Sciences Humaines et des Sciences de l'Education, Université des Lettres et des Sciences \\ Humaines de Bamako, Bamako, Mali \\ Correspondence: Oumou Diallo, School of Humanities and Social Sciences, Beijing Forestry University, 100083, \\ Beijing, P.R. China. Tel: 86-183-1104-5956. E-mail: oumou_ladialose@yahoo.fr
}

Received: November 9, 2015

Accepted: December 10, 2015 Online Published: December 17, 2015

doi:10.5539/ijps.v8n1p53

URL: http://dx.doi.org/10.5539/ijps.v8n1p53

\begin{abstract}
This study is based on the livelihood used by street children for survival in Bamako, Mali. Two bus stations were selected for this study: Sogoniko bus station and Medina bus station. Most buses leave from these stations to the vicinity of the country. Data was collected through individual interviews (one by one), focus group discussions and interviews. A sample of one hundred and twenty street children aged between 8 and 17 years were selected for this study. Thirty people were also selected to give their opinions on street children. The results indicate that most of street children survive by selling small objects and through begging, $32.5 \%$ and $22.50 \%$ respectively. Our survey indicates that there are different factors pushing them to the streets, and as a way of survival on the streets, there is need to be organized, hence, they are organize themselves into groups for protection against violence and aggressions.
\end{abstract}

Keywords: livelihood, street children, survival

\section{Introduction}

\subsection{The Phenomenon of Street Children}

The phenomenon of street children takes a large scale. Today, this phenomenon is spreading in countries where it did not exist before (Volpi, 2002). Before the 80s, Mali did not know the phenomenon of street children, all children belonged to a family structure. There was a strong family unit. A child could not be rejected by his parents without being recovered by someone else, as children in African traditional society belong to the community. These ideas of large extended families tend to disappear due to economic difficulties. Today in Mali we meet many children on the streets (Cisse, 2009).

The causes of street children are multiple and vary. According to Douville (2006), it is the massive urbanization of the recent decades which made children who are considered as pillars of families in rural areas to go and live in the difficult condition of city life. Many people are leaving rural areas to cities for better living conditions. The bad effect of urbanization can lead people to take drugs, be victim of accident or imprisonment. More worryingly, this urbanization movement has profound effects on the physical and emotional health of children (Gracey, 2002). The phenomenon of street children is increasing due to migration to urban cities. United Nations Children's Fund (UNICEF) (1993), point out that working of street children is related to the deterioration of economic circumstances. Mella (2012), argues out that it is poverty that forces African children to work on the streets. This poverty makes many families divide and lead children to urban areas with the hope of a better future. In Mali, the cotton sector appears as the first job provider (Bagayogo, 2014). Despite her potential, Mali remains one of the less developed countries in the world.

UNICEF (2012) suggested that there are more than ten millions children living and working on streets in the World. In Mali it is difficult to give an exact number of street children. These children possess nothing like identity card. 


\subsection{Livelihood}

A livelihood is defined as a combination of factors that one individual utilizes to make his/her means of living (Kobayashi, 2004).

Street children earn their livelihood through work. On the streets, they are active in legal and illegal activities to earn income (ADUGNA, 2006; Smeaton, 2011). The boys are engaged in economic activities such as washing cars, throwing garbage, drawing water or selling plastic bags. A large number of girls are engaged in prostitution as an important source of income (Mtonga, 2011). UNICEF (1993) showed that on the street there are visible and less visible children. The visible, are those who work as vendors such as shoes-shiners, baggage carriers, and so on. Those who are less visible work in back-room bars, kitchen quarters or in factories. In Bamako at night, the most visible children are boys. The girls are less visible. They work as prostitutes and spend the night with their customers (Hatloy \& Huser, 2005).

Struggling to survive, they are exposed to dangerous situations. They are vulnerable to illnesses and bad situations which can drive them to death (UNICEF, 2012). For example, in India, most street children were found with wounds and scars as a result of violent beatings (Rao, 2008).

\subsection{Street Children}

In this study it is important to define the street children. UNICEF gives two terms for street children: children of the street and children on the street (Andrea et al., 2014). However, Children of the street are distinctly different from Children on the street (Lugalla \& Mbwambo, 1999). Children of the street are those who have a complete broken relationship with their family. They live and sleep alone on the street; children on the street are those generally who leave home in the morning, working on the street and bring income for the family. They work on the street but return home in the evening. In this case, the child remains in constant contact with their parents or family.

\section{Research Aims and Objective}

In Mali the street children live in very difficult conditions. They walk all day in search of work, money or food. They are exposed to traffic hazards and malnutrition. During the cold and rainy seasons, they are left out. Thus they suffer from many diseases such as tuberculosis, malaria, and diarrhea and so on. Further, these children do hazardous work that may affect their health. Therefore, we decided to make this study on street children in Mali. The aim of this study is to identify livelihood used by street children of Bamako for survival.

\section{Study Areas}

Mali is a landlocked country in West Africa. It covers an area of $1,241,238 \mathrm{~km}^{2}$. It shares $7420 \mathrm{~km}$ border with 7 neighboring countries: Algeria, Niger, Burkina Faso, Côte d'Ivoire, Guinea, Mauritania and Senegal. Bamako is the capital and the largest city in Mali. Located on the banks of the Niger River, Bamako district covers an area of $267 \mathrm{~km}^{2}$ and a population of 1809106 inhabitants according to the last administrative census in 2009. In the district of Bamako, we have six communes. Each headed by a mayor assisted by a municipal council. Bamako city experienced rapid urban growth with $5.4 \%$ (being the 6th rank in the world by its growth rate). The population growth is due to both significant soil fertility and significant migration.

The climate of the city of Bamako is Sudanese type. It is marked by a rainy season (early June to September) and a dry season (October to May).

\section{Method}

Two bus stations were selected for this study: Sogoniko and Medina bus stations. Most buses leave from these stations to the vicinity of the country. They receive transport vehicles, passengers and goods from others sub regions.

\subsection{Participants}

One hundred and twenty street children aged between 8 and 17, and thirty people were selected for this study. Out of a total sample of one hundred fifty participants, $49.16 \%$ answered the questions one by one and $50.83 \%$ took part in the focus group discussion. From the thirty adults, only 9 were women.

\subsection{Procedure and Measures}

One by one interview, focus group discussions, interviews with some people were used to collect data. Boys (51) and girls (8) had responded to the individual interview: what are your reasons for being on the street? What is your wish in the near future? What is your original Residence? Do you have relations in Bamako? 55 boys and 6 girls were interviewed through focus group discussions where they were asked: how do you manage to meet 
your needs? Where do you sleep? Thirty people (21 men and 9 women) were selected to give their views on street children. Natural observation was one of the instruments used.

\subsection{Collection of Data}

The 120 children in the two areas were interviewed one by one, and in groups. Given their low level of education, the investigators had to translate the questions into the national language (Bambara). The responses were recorded and photos were also taken. Only children who are on the street were interviewed. During the interview the children who felt embarrassed to answer the questions in public, were taken to private places. To carry out this study, four assistants were recruited. The investigation lasted three months and fifteen days. The street children who agreed to participate in the survey answered all the questions. At the beginning of the investigation, the children had refused to participate because no money was given. So every child was rewarded with a sum of 0.33 \$. Despite this, others still refused to participate.

\section{Results}

During natural observation, some children were seen selling various items such as paper tissues, chewing gums, biscuits, water, and candies. Others were observed repairing motorcycles, helping passengers quickly find the bus and polishing shoes. While some engaged in the early mentioned work, others stood by traffic lights to beg or wash cars. The observation was made in the morning, the day and the night. It lasted six days. This technic allowed us to collect data on street children in Bamako.

Table 1. Age and number of children who participated in the study

\begin{tabular}{llllll}
\hline & \multicolumn{2}{c}{ Boy } & \multicolumn{2}{c}{ Girl } & Total \\
\cline { 2 - 5 } & Age & Number (\%) & Age & Number (\%) & \\
\hline Focus group & $9-17$ & $55(45.83)$ & $13-17$ & $6(5)$ & $61(50.83)$ \\
Interview one by one & $11-17$ & $51(42.5)$ & $13-17$ & $8(6.66)$ & $59(49.16)$ \\
\hline
\end{tabular}

As shown in Table 1, there are 55 boys aged 9-17 in focus group 51 boys aged 11-17 who adopted interview one by one. The majority of the street children are boys (88.33\%) against (11.67) girls. While 6 girls aged 13-17 participated in the focus group interviews and 8 girls participated in the one by one interview.

Table 2. Presents the socio-demographic characteristics of respondents

\begin{tabular}{llll}
\hline $\begin{array}{l}\text { Reasons that push children to go on } \\
\text { the streets }\end{array}$ & \multicolumn{2}{c}{ Gender } & Total \\
& Boy number (\%) & Girl number (\%) & \\
\hline Poverty & $40(33.33)$ & $9(7.5)$ & $49(40.83)$ \\
Violence & $20(16.66)$ & $3(2.5)$ & $23(19.16)$ \\
Death of parents & $6(5)$ & $2(1.66)$ & $8(6.66)$ \\
Conflict with teachers & $30(25)$ & - & $30(25)$ \\
Quarrel of parents & $10(8.33)$ & - & $10(8.33)$ \\
\hline Original Residence & & & $15(12.49)$ \\
\hline Urban & $13(10.83)$ & $2(1.66)$ & $105(87.5)$ \\
Rural & $93(77.5)$ & $12(10)$ & $9(7.49)$ \\
\hline Relationship in Bamako & & & $111(92.49)$ \\
\hline Relation & $8(6.66)$ & $1(0.83)$ & \\
No relation & $98(81.66)$ & $13(10.83)$ & $96(80)$ \\
\hline Wish in near future & & $9(7.5)$ & $24(19.99)$ \\
\hline Leave the street & $87(72.5)$ & $5(4.16)$ & \\
Return at home & $19(15.83)$ &
\end{tabular}


Table 2 shows the socio-demographic characteristics of respondents. Children are exposed first to poverty. On the 120 children surveyed, $40.83 \%$ indicates that poverty was the main cause of their presence on the streets. This was the main reason that led them to abandon their families for the streets.

Diarra is a boy of aged 15. He left his family because of economic hardships. He was born in a polygamous family. His father owned a bakery that was working well. He had married four women. As the bakery didn't work as good as before. His father had difficulties to feed his family. To take the three daily meals, his mothers were washing clothes for other people just to earn something to support the family. "I did not eat well, thus I left my family. I will go back if my father finds money".

The conflict with teacher is the second reason that led the boys to live on the streets (about $25 \%$ as shown). More than $19 \%$ of the children mentioned above have suffered from violence in their families. Generally these are the lashes, but also hard labor. For example construction work, field work and other labor demanding jobs. About $8.33 \%$ of boys mentioned quarrel with both parents. But this case is nonexistent in girls. Moussa is a 17 years old boy. He left his home because of the quarrels with his parents. "Whenever my parents quarrel, my father says that my mother gave birth to nothing good. To honor my mother I left home. I took a bus to come to Bamako. When I arrived, I firstly used to sleep in the bus station. Now, I took a room that I pay for by myself. I want to avenge the insult to my mother".

In the end we also have about $8 \%$ orphaned children whose both parents have died. These are children who have fled armed conflict and who have lost track of their parents who are either dead or living some else.

\subsection{Original Residence}

About $87.5 \%$ of the children reside in rural areas. And only $12.49 \%$ of them are declared to be from urban areas.

\subsection{Relationship in Bamako}

They fled various situations desiring to come and live in Bamako in search of better living conditions. Most of these children $92.49 \%$ have no relations in Bamako.

\subsection{Wishes in Near Future}

About $80 \%$ of the children are looking forward to get through this miserable and hard conditioned life and enjoy brighter and happier lives in the future. They wanted to become great traders, build beautiful houses, and get married to a very beautiful woman and to have a lot of money.

Table 3. Livelihoods used by street children for survive

\begin{tabular}{llll}
\hline Strategy for survive & \multicolumn{2}{c}{ Gender } & Total \\
\cline { 2 - 3 } & $\begin{array}{l}\text { Boy } \\
\text { Number (\%) }\end{array}$ & $\begin{array}{l}\text { Girl } \\
\text { Number (\%) }\end{array}$ \\
\hline Car washing & $15(12.5)$ & & $15(12.5)$ \\
Carrying luggage & $7(5.83)$ & & $7(5.83)$ \\
Shoe shine & $11(9.16)$ & & $11(9.16)$ \\
Begging & $27(22.5)$ & $14(11.66)$ & $22(22.50)$ \\
Selling & $25(20.83)$ & & $39(32.5)$ \\
Repairing motorcycles & $9(7.5)$ & & $9(7.5)$ \\
Stealing & $12(10)$ & & $12(10)$ \\
\hline Sleeping places & & & \\
\hline Station & $97(80.83)$ & $12(10)$ & $47(80.33)$ \\
Under bridges & $4(3.33)$ & $2(1.66)$ & $17(14.16)$ \\
Home & $5(4.16)$ & $2(1.66)$ \\
Bar & & & \\
\hline
\end{tabular}




\subsection{Livelihoods}

Concerning livelihood Table 3 indicates that $32.5 \%$ of the children (boys and girls) have declared the sale of various items. For example sweets, biscuits, Kleenex, water... We did not find girls to be beggars, while about $22.5 \%$ of the boys were beggars. According to the terms of beggar respondent, every day they form groups of three and go in families or they hold their empty box out to passers. This strategy allows them to earn some money and food often cereals, and even some clothes. After which they would sell the cereals to shopkeepers.

Whereas in Mali, in the report on the Children's Charter, article 183 of the Penal Code punishes the incitement of child begging: "Any beggars found on the roads should be imprisoned for fifteen days minimum to six months maximum. Even those that push the children to begging should be imprisoned for three months minimum to a maximum of one year" (Charte Africaine des Droits et du Bien-être de l'Enfant, 2007). About 12.5\% of the children had mentioned car washing. These are children who stop at traffic lights with liquids for washing cars and cloths for drying them. They wash the outer windows for vehicles passing by. The drivers who have mercy will gives them money. This lifestyle allows them to make a living on the streets. We have found children who carry luggage to be $5.83 \%$ of the street children's population. They carry especially travelers' luggage. Shoe shining covered about $9.16 \%$ of the children, and motorcycle repairing about $7.5 \%$. While some work, others survive by stealing. As a child had mentioned when asked about his survival pattern. He said, "we are a group of 5 children, we circulate in big markets to steal from traders: clothes, jewelries that we resell after a few months in others places".

Children are organized into groups of gangs. Each gang defends its territory. Those who beg constitute a group, those who steal are in their group, those who sell form their own group and so on. Integration into a group starts with the initiation that involves smoking, drink or consumes glue. This initiation demonstrated their strength and their ability to be a member of the group. They are all submitting to the authority of an older child who is generally the leader of the group. The leader status gives the child authority over others. In Mali they are nicknamed "Gnemogo". They can hit or force others to drink. His wish is the order of the day. However, they remain together and solidary; they help each other in lending money, clothes, shoes, and fighting together against aggression.

\subsection{Sleeping Places}

Places such as under bridges, Bars, Stations were some places indicated by children to be where they spend their nights. From the 120 children, only seventeen children sleep at home.

\section{Discussions}

The current study examined the livelihood used by street children for survival. In a sample of 120 street children, the data analyzed had been based on the interviews. The individual interview requested them to tell their reasons for being on the streets, their original residence, if they have relations in Bamako and their wishes in the future. The focus group discussion requested them to say how they manage to meet their needs and their sleeping places. The analyses revealed that children survive on the street by different means: begging (22.5\%), selling small articles $(32.5 \%)$, car washing $(12.5 \%)$, carry luggage $(5.83 \%)$ shoe shinning $(9.16 \%)$, repair motorcycle $(7.5 \%)$ and stealing $(10 \%)$. However, for protection against aggressions, they are organized into group. The various means of livelihood that street children use in our study for survival were also observed in street children of other countries. For example in Bangladesh, Md.Sirajul Islam, Md.Esfaqur Rahman, and Khatun (2013) have reported street children begging, sell fish or being assistants to fish sellers. They continued to say that, they are shoe-shiner, or hawker. Another study on street children in Harare showed also that street children sale roses, hawk sweets and fruits, beggars, carriers of luggage and car washers (Mella, 2012). However, they rarely sell newspapers (Ritah Marima, Jordan, \& Cormie, 1995).

From our data, the following numbers represent street children's population by gender $(88.33 \%)$ boys and (11.67\%) girls respectively. Our results are in line with the study taken by Boas and Hatloy (2008) who also found that Bamako had $96 \%$ of boys on the street and $9 \%$ orphaned children. That means that girls are rarely seen on the street.

Findings showed poverty $(40,83 \%)$ as the main reason that pushes children to go on the streets. Our findings are consistent with previous research by Sababou (2009) in Mali, Demartoto (2012) in Indonesia, Paul (2011) in Democratic Republic of the Congo, Conticini and Hulme (2006) in Bangladesh. In addition, some street children sacrifice their childhood to help their families going through economic difficulties and because their parents are helpless to satisfy their families' needs. Conflict with teachers $(25 \%)$ explains a much bigger part of these children's existence on the streets. Some children who end up as beggars are sent by their parents to the capital 
for school to learn the Quran. But some of the teachers mistreat them; they make them beg on the street. This finding is consistent with findings from a study conducted in Mali by KONE (2010) which reported 28\% boys who fled abuse from their Quran teachers. In contrast, we did not find any similar result on the conflict with the master in others countries. Street children in Mali ask for alms for survive, on the contrary, the street children in Nigeria do not ask for alms unless if they have nothing to eat (Omiyinka, 2009).

From the thirty peoples interviewed, the majority thought these children are on the streets in search to satisfy their basic needs, hence, they practice all kinds' of activities on the street. All participants said that the government must help these street children. One of the respondents said, "In life we need many things, these children also seek to satisfy their needs which cause them to steal from passers, traders or to beg. They are rejected by society which considers them as delinquent. The government needs to find an effective way to stop this phenomenon". Another respondent said that these children do not eat well. Also the money they earn is mainly spent on buying alcohol, drugs than food. For the good of Malian society, He thinks that the government must help them to leave streets because they are the people who end becoming dangerous criminals in the future. "In the end, street children are human beings just like all of us. They live on the street and work in miserable conditions. Most of them consume drugs. The government needs to put more effort in the integration of these young people." Added another respondent.

These results suggest that being Mali is a signatory to the United Nations Convention on the Rights of the Child, it must fight against the scourge of children on the street, and it must:

- Improve the living conditions of the street children to bring them to normal life.

- Sensitize the parents the dangers of pushing children onto the streets, through movies, shows on the television and radio.

- The state must strengthen its fight against poverty in order to help families in difficulties, and prevent cases of home abandonment because of poverty.

- Apply laws that fight against begging.

- Strengthen the capacity of Non-Governmental Organization (NGO) in the care of street children.

- Create training centers for children. Send more teachers and doctors in these centers. While in the centers, teach them how to read and write at the same time and control the health status of these children.

- Source for more funding to build a better future for these young people who have not chosen their current situation.

- Mobilize Non-Governmental Organization (NGO), religious leaders and civil societies for the cause of eliminating street childhood in Mali.

\section{Conclusion}

Street children in Bamako live in difficult conditions. Many of them left rural areas for the capital. They sleep in the open or in empty buildings, and they have no one to support them in their daily struggle. In bus stations, they sleep on benches or even on the floor. The meal quotient is not guaranteed. They suffer from malnutrition, violence and many contagious diseases. This can cause them to have physical and psychological problems and bring serious consequences in the long-run. However these young boys and girls dream of having a better future someday. The aim of this study was to describe in detail how the street children in Bamako earned their livelihoods. The results reveal that street children survive thanks to legal and illegal activities. They try to find their place on the streets to survive and meet life's basic needs. Data was collected from interviews and all participants answered.

\section{Acknowledgement}

The authors wish to thank the Beijing Municipal Government. 


\section{References}

ADUGNA, G. (2006). Livelihoods and Survival Strategies Among Migrant Children in Addis Ababa (Master of Philosophy in Development Studies ). Norwegian University of Science and Technology (NTNU).

Andrea F. M. et al. (2014). Exposure to maltreatment and urban violence in children working on the streets in Sa o Paulo, Brazil: Factors associated with street work. Revista Brasileira de Psiquiatria, 36, 191-198. http://dx.doi.org/10.1590/1516-4446-2013-1185

Bagayogo, K. (2014). L'importance et L'avenir du Coton en Afrique de l'Ouest: Cas du Mali (Thèse pour obtenir le grade de docteur). Université de Grenoble.

Boas, M., \& Hatloy, A. (2008). Child Labour in West Africa: Different Work-Different Vulnerabilities. Journal Compilation, 46(3). http://dx.doi.org/10.1111/j.1468-2435.2008.00460.x

Charte Africaine des Droits et du Bien-être de l'Enfant. (2007). Premier rapport du Mali sur la mise en ouvre de la charte africaine des droits et du bien-être de l'enfant.

Cisse, S. (2009). L'Apport de Caritas-Mali dans l'Insertion des Enfants de la Rue (Maitrise Sciences de l'Education). Faculte des Lettres, Langues, Arts et Sciences Humaines.

Conticini, A., \& Hulme, D. (2006). Escaping Violence, seeking freedom: Why Children in Bangladesh Migrate to the Street (p. 46). Global Poverty Research Group (GPRG).

Demartoto, A. (2012). Need-Based Street Children Management in Surakarta City of Central Java Province of Indonesia. Canadian Center of Science and Education, 8. http://dx.doi.org/10.5539/ass.v8n11p107

Douville, O. (2006). Enfants et Adolescents en Danger dans la Rue à Bamako, Mali. Psychopathologie africaine. Psychopathologie africaine, $H^{\wedge}$ opital de Dakar, Fann, XXXII(1), 55-89.

Gracey, M. (2002). Child health in an urbanizing world. Acta paediatrica, 91(1), 1-8. http://dx.doi.org/10.1111/j.1651-2227.2002.tb01629.x

Hatloy, A., \& Huser, A. (2005). Identification of street children. Characteristics of street children in Bamako and Accra (p. 96).

Kobayashi, M. Y. (2004). Economic Livelihoods for Street Children (p. 85). 7250 Woodmont Avenue, Suite 200, Bethesda, Maryland 20814.

Kone, J. D. (2010). Le Samusocial Mali et la prise en charge médico-psycho-sociale des enfants de la rue en situation d'urgence sociale. Quelles problématiques pour quelles prises en charge (Diplôme supérieur en travail social maitrise). Institut national de formation des travailleurs sociaux.

Lugalla, J. L. P., \& Mbwambo, J. K. (1999). Street Children and Street Life in Urban Tanzania: The Culture of Surviving and its Implications for Children's Health. Joint Editors and Blackwell Publishers Ltd 1999. http://dx.doi.org/10.1111/1468-2427.00198

Md.Sirajul, I., Md.Esfaqur, R., \& Khatun, R. (2013). Street Children Struggle For Survival Where Protection Of Human Resource Development: (A Study On Khulna City, Bangladesh.). 14.

Mella, M. (2012). An Investigation into the Nature and Extent of Economic Exploitation of Street Children in Zimbabwe: A case Study of Harare Central Business District ( Master of Social Work Master ). University of Zimbabwe.

Mtonga, J. (2011). Children Moving Between Institutional Care and Survival on the Streets (Master of Philosophy in Childhood Studies). Norwegian University of Science and Technology Norwegian Centre for Child research (NOSEB).

Omiyinka, F. O. (2009). Social Networks and Livelihood of Street Children in Ibadan, Nigeria. International Journal of Sociology and Anthropology, 1(5), 82-89.

Paul, B. (2011). phénomène enfants de la rue comme facteur criminogène dans la cité de Bunia (Travail de fin de cycle). Universite du Cepromad Bunia RDC.

Rao, M. (2008). Beyond survival-A Status Report on Livelihood. In Programmes for Street Youth in India (p. 44).

Ritah, M., Jordan, J., Cormie, \& Kenna. (1995). Conversations With Street Children in Harare, Zimbabwe, 22, $1-24$. 
Sababou, C. (2009). L'Apport de Caritas-Mali dans l'Insertion des Enfants de la Rue (Maitrise Memoire de Maitrise). Faculte des Lettres, Langues Arts et Sciences Humaines.

Smeaton, E. (2011). Children Living Alone on the Streets in Tanzania and Kenya (p. 91). Railway Children Africa.

United Nations Children's Fund (UNICEF). (1993). Street and Working Children (p. 57).

United Nations Children's Fund (UNICEF). (2012). The State of the World's Children 2012: Children in an Urban World (p. 156).

Volpi, E. (2002). Street Children: Promising Practices and Approaches (p. 37). The International Bank for Reconstruction and Development/The World Bank 1818 H Street, N.W. Washington, D.C. 20433, U.S.A.

\section{Copyrights}

Copyright for this article is retained by the author(s), with first publication rights granted to the journal.

This is an open-access article distributed under the terms and conditions of the Creative Commons Attribution license (http://creativecommons.org/licenses/by/3.0/). 